\title{
Mój pacjent leczony sulodeksydem - kiedy i dlaczego stosuję?
}

\section{My patient treated with sulodexide - when and why I use this drug?}

\author{
Iwona Gorczyca ${ }^{1}$, Beata Wożakowska-Kapłon ${ }^{1,2}$ \\ ${ }^{1}$ I Klinika Kardiologii i Elektroterapii Świętokrzyskiego Centrum Kardiologii w Kielcach \\ ${ }^{2}$ Wydział Lekarski i Nauk o Zdrowiu Uniwersytetu Jana Kochanowskiego w Kielcach
}

\section{Streszczenie}

Żylna choroba zakrzepowo-zatorowa (VTE) jest częstą przyczyną śmiertelności, zarówno podczas pierwszej manifestacji, jak i w postaci nawrotów. Ryzyko nawrotu choroby jest najwyższe u chorych z VTE niesprowakowaną i w przypadku zakrzepicy żył głębokich w odcinku proksymalnym. Po obligatoryjnym 3-miesięcznym okresie leczenia przeciwkrzepliwego u chorych z VTE należy rozważyć wskazania do długotrwałego leczenia przeciwkrzepliwego. Przestawiono aktualny stan wiedzy na temat profilaktyki nawrotu choroby oraz opis przypadku klinicznego obrazujący codzienne wybory podejmowane $u$ chorych z grupy najwyższego ryzyka sercowo-naczyniowego.

Słowa kluczowe: sulodeksyd, zakrzepica żył głębokich

Folia Cardiologica 2017; 12, 6: 580-588

\section{Wstęp}

Żyına choroba zakrzepowo-zatorowa (VTE, venous thromboembolism) manifestuje się jako zakrzepica żył głębokich (DVT, deep vein thrombosis) lub zatorowość płucna (PE, pulmonary embolism). Obie te postaci mogą współistnieć lub występować osobno. Źródło zatoru tętnicy płucnej stanowi najczęściej proksymalna DVT - aż 90\% materiału zatorowego pochodzi z odcinka proksymalnego żył głębokich kończyn dolnych. Poza tym źródło zatoru u chorych z PE mogą stanowić zakrzepica żył miednicy mniejszej, zakrzepica żył nerkowych, żyły głównej dolnej oraz zakrzep/ /skrzep przy cewniku w żyłach centralnych [1, 2]. Szacuje się, że u połowy pacjentów z proksymalną DVT kończyn dolnych występuje bezobjawowy zator tętnicy płucnej [3].

Zakrzepica żył głębokich (zwykle bezobjawowa) jest rozpoznawana u około $70 \%$ pacjentów z objawowym zatorem tętnicy płucnej [4]. Zastój żylny, zmiana składu krwi oraz zmiany śródbłonka ujęte w triadę Virchowa to znane czynniki odpowiadające za rozwój VTE. Wystąpienie VTE następuje zwykle wtedy, gdy współistnieją co najmniej dwa wymienione czynniki. Zidentyfikowano wiele czynników, których obecność zwiększa ryzyko wystąpienia VTE; należą do nich między innymi: unieruchomienie, uraz, operacja, zakażenie, ciąża, wiek powyżej 40 lat, nowotwór złośliwy, trombofilia. Przebyte DVT oraz PE także predysponują do kolejnych epizodów choroby, dlatego bardzo istotna jest ocena chorego pod kątem nawrotu choroby i ustalenie optymalnego czasu leczenia przeciwkrzepliwego.

\section{Epidemiologia VTE}

Benard i wsp. [5] wykazali, że incydenty DVT występowały u około 120/100 tys. osób/rok, a roczną częstotliwość występowania PE oszacowano na 60-111/100 tys. osób/ 
/rok. Zapadalność na VTE zwiększa się istotnie z wiekiem [6]. Wzrasta ona wyraźnie od wartości poniżej 1/100 tys. osób/rok u dzieci, przez 30/100 tys. osób/rok u osób młodych do ponad 500/100 tys. osób/rok po 70. roku życia. Analiza amerykańskiej bazy danych w obserwacji 21-letniej wykazała, że częstość występowania DVT była istotnie większa u pacjentów powyżej 70. roku życia niż u osób w wieku 20-69 lat. Także zator tętnicy płucnej występował znacznie częściej u osób starszych, jednak w ciągu ostatnich 10 lat obserwacji częstość występowania tej postaci VTE nie wzrosła [6]. Szacuje się, że w Polsce rocznie na DVT choruje około 50 tys. osób, a na PE około 20 tys. chorych [7]. Wydaje się, że VTE jest rozpoznawana w niedostatecznym stopniu, co wynika z niewystarczającej świadomości częstości występowania tej choroby, różnej manifestacji klinicznej zatoru tętnicy płucnej i DVT oraz niedostatecznej dostępności testów diagnostycznych, pozwalających w jednoznaczny sposób rozpoznać zator tętnicy płucnej oraz DVT.

\section{Czynniki ryzyka VTE}

Ryzyko wystąpienia VTE jest niejednorodne. Znane są różne podziały i próby zdefiniowania grup czynników ryzyka tej choroby. Można je podzielić na czynniki ryzyka kliniczne (związane z unieruchomieniem, z zastosowanym leczeniem oraz pozostałe czynniki kliniczne, takie jak wiek, schorzenia współistniejące, ciąża) oraz biochemiczne, a wśród nich trombofilie wrodzone i nabyte. Szczególną grupę stanowią pacjenci poddawani zabiegom operacyjnym. Ryzyko związane $z$ wystąpieniem okołooperacyjnej i pooperacyjnej DVT zależy nie tylko od ryzyka związanego z rodzajem wykonywanego zabiegu, lecz także od wspótistniejących indywidualnych czynników ryzyka, których znaczenie kliniczne może być znacznie większe niż zagrożenie związane $z$ rodzajem wykonywanego zabiegu. Skalę oceny ryzyka VTE zaproponował Caprini i dotyczy ona chorych poddawanych zabiegom chirurgii ogólnej. Oceniane są różnorodne czynniki podane w tabeli 1 [8].

Tabela 1. Czynniki predysponujące do wystąpienia żylnej choroby zakrzepowo-zatorowej (VTE, venous thromboembolism) u chorych poddawanych zabiegom chirurgicznym (źródło [8])

\begin{tabular}{|c|c|c|c|}
\hline \multicolumn{4}{|c|}{ Punktacja } \\
\hline 1 & 2 & 3 & 5 \\
\hline Wiek 41-60 lat & Wiek 61-74 lat & Wiek $\geq 75$ lat & Udar mózgu (< 1 mies.) \\
\hline Mały zabieg operacyjny & Zabieg artroskopowy & Przebyta VTE & Planowa alloplastyka stawu \\
\hline $\mathrm{BMI}>25 \mathrm{~kg} / \mathrm{m}^{2}$ & Duży zabieg chirurgiczny & VTE w wywiadzie rodzinnym & Złamanie kości miednicy, kości \\
\hline Obrzęk kończyn dolnych & (> 45 min) & Czynnik V Leiden & udowe lub koscı podudzıa \\
\hline Żylaki kończyn dolnych & & Mutacja G20210A genu & Uszkodzenie rdzenia \\
\hline Ciąża lub okres połogu & (> $45 \mathrm{~min})$ & protrombiny & kręgowego (< 1 mies.) \\
\hline Przebyte niewyjaśnione lub & Nowotwór złośliwy & Lek przeciwkrzepliwy & \\
\hline nawykowe poronienia & Pozostawanie w łóżku & Antykoagulant toczniowy & \\
\hline Doustna antykoncepcja lub & & Przeciwciała & \\
\hline Sepsa $(<1$ mies $)$ & Unieruchomienie gipsowe & antykardiolipinowe & \\
\hline Poważna choroba płuc, w tym & Cewnik w żyle centralnej & Przeciwciała anty-b2-GPI & \\
\hline zapalenie płuc (< 1 mies.) & & Zwiększone stężenie & \\
\hline Zaburzenia czynności płuc & & homocysteiny w surowicy & \\
\hline Ostry zawał serca & & HIT & \\
\hline $\begin{array}{l}\text { Zaostrzenie lub rozpoznanie } \\
\text { niewydolności serca }\end{array}$ & & $\begin{array}{l}\text { Inna wrodzona lub nabyta } \\
\text { trombofilia }\end{array}$ & \\
\hline$(<1$ miesiąc $)$ & & & \\
\hline $\begin{array}{l}\text { Choroba zapalna jelit w wy- } \\
\text { wiadzie }\end{array}$ & & & \\
\hline $\begin{array}{l}\text { Chory leczony zachowawczo, } \\
\text { pozostający w łóżku }\end{array}$ & & & \\
\hline
\end{tabular}


Uzyskanie w prezentowanej skali 0 punktów oznacza bardzo małe ryzyko, 1-2 punktów - niskie ryzyko, 3-4 punktów - umiarkowane ryzyko, a wynik równy 5 punktom lub wyższy oznacza wysokie ryzyko wystąpienia powikłań zakrzepowo-zatorowych. Oszacowanie ryzyka powikłań zakrzepowo-zatorowych umożliwia włączenie profilaktyki przeciwzakrzepowej przeznaczonej dla chorych z grup umiarkowanego i wysokiego ryzyka.

\section{Nawrotowość VTE}

Nawrotowość VTE zależy przede wszystkim od etiologii choroby, lokalizacji zmian zakrzepowych oraz schorzeń współistniejących. Najwyższy odsetek nawrotów występuje u chorych z niesprowokowanym (idiopatycznym) epizodem PE lub DVT. Niesprowokowany pierwszy epizod DVT odcinka proksymalnego lub idiopatycznej postaci PE wiąże się dużym ryzykiem nawrotu choroby po zakończeniu terapii przeciwkrzepliwej, szacowanym na 6-10\% w 1. roku, 20\% w 2. roku i 30\% po 5 latach [9]. U pacjentów z dystalną postacią DVT ryzyko nawrotu jest o 50\% niższe niż u chorych z jej proksymalną lokalizacją, natomiast u chorych z drugim epizodem idiopatycznej DVT lub niesprowokowanej PE o 50\% wyższe niż ryzyko związane z pierwszym epizodem VTE $[10,11]$. Prandoni i wsp. [10], w badaniu obejmującym 1626 chorych leczonych przeciwkrzepliwe z powodu PE lub VTE ocenili częstość występowania nawrotu choroby u osób z idiopatyczną i sprowokowaną VTE w ciągu 10-letniej obserwacji, po zaprzestaniu leczenia przeciwkrzepliwego (tab. 2). Częstość występowania nawrotu choroby była wyższa u chorych z idiopatyczną VTE. Zidentyfikowano czynniki predysponujące do wystąpienia nawrotu choroby, były to: niesprowokowana VTE, trombofilia, DVT, trwające krócej niż 6 miesięcy leczenie przeciwkrzepliwe oraz wiek [10].

Oznaczenie stężenia D-dimeru po zakończeniu antykoagulacji u chorych leczonych z powodu VTE jest prostym sposobem pozwalającym na ocenę ryzyka nawrotu choroby. Palareti i wsp. [12]. ocenili stężenie D-dimeru u 619 chorych z idiopatyczną VTE miesiąc po zaprzestaniu stosowania leczenia przeciwkrzepliwego. U chorych, u których stężenie D-dimeru było podwyższone, kontynuowano leczenie przeciwkrzepliwe lub odstąpiono od antykoagulacji, natomiast u chorych, u których stężenie D-dimeru było prawidłowe, odstąiono od leczenia przeciwkrzepliwego. W trakcie 18-miesięcznej obserwacji odsetek nawrotu choroby był najniższy $(2,9 \%)$ u chorych z podwyższonym stężeniem D-dimeru przewlekle antykoagulowanych. U chorych z podwyższonym stężeniem D-dimeru niepoddanych leczeniu przeciwkrzepliwemu wynosił on 15\%, a u chorych z wyjściowo prawidłowym stężeniem D-dimeru - 6,2\% [12]. Zaproponowano stratyfikację ryzyka nawrotu choroby na podstawie skali DASH (D-dimer, age, sex, hormonal therapy), według której ryzyko u chorego należy obliczyć następująco:

- nieprawidłowe stężenie D-dimeru po zakończeniu antykoagulacji + 2 punkty;

- wiek poniżej 50 lat + 1 punkt;

- płeć męska + 1 punkt;

- stosowanie doustnej antykoncepcji przy zachorowaniu +2 punkty [13].

U chorych z wynikiem w skali DASH wynoszącym 1 punkt roczny odsetek nawrotów wynosił 3,1\%, u chorych z 2 punktami w tej skali - 6,4\%, a u pacjentów, którzy uzyskali co najmniej 3 punkty, roczny odsetek nawrotów VTE wynosił 12,3\% [13].

W modelu Vienna, służącym ocenie ryzyka nawrotu VTE, uwzględniono stężenie D-dimeru, płeć oraz lokalizację zakrzepicy [14]. Model Vienna opracowano na podstawie obserwacji trwającej średnio 43,3 miesiąca po zaprzestaniu leczenia przeciwkrzepliwego u 929 chorych z niesprowokowaną, pierwszorazową VTE. U 18,9\% chorych obserwowano nawrót choroby. Wykazano, że płeć męska, zakrzepica żył proksymalnych, PE oraz podwyższone stężenie D-dimeru były czynnikami predysponującymi do nawrotu choroby. Korzystając z prostych skal, takich jak DASH lub Vienna, można w prosty sposób określić ryzyko nawrotu VTE, a tym

Tabela 2. Skumulowana częstość występowania nawrotu żylnej choroby zakrzepowo-zatorowej (VTE, venous thromboembolism) u chorych z niesprowokowaną i sprowokowaną VTE (źródło [10])

\begin{tabular}{|c|c|c|c|c|c|c|}
\hline \multirow{2}{*}{$\begin{array}{l}\text { Miesiąc } \\
\text { obserwacji }\end{array}$} & \multicolumn{3}{|c|}{ Idiopatyczna VTE } & \multicolumn{3}{|c|}{ Wtórna VTE } \\
\hline & $\begin{array}{l}\text { Liczba } \\
\text { chorych }\end{array}$ & $\begin{array}{c}\text { Skumulowana } \\
\text { częstość } \\
\text { występowania (\%) }\end{array}$ & $95 \% \mathrm{Cl}$ & $\begin{array}{l}\text { Liczba } \\
\text { chorych }\end{array}$ & $\begin{array}{l}\text { Skumulowana } \\
\text { częstość } \\
\text { występowania(\%) }\end{array}$ & $95 \% \mathrm{Cl}$ \\
\hline 6. & 85 & 10 & $8-12$ & 32 & 4,2 & $2,8-8,7$ \\
\hline 12. & 39 & 15 & $12,6-17,4$ & 17 & 6,6 & $4,8-8,4$ \\
\hline 36. & 74 & 26,3 & $23-29,6$ & 34 & 12,3 & $9,8-14,8$ \\
\hline 60. & 56 & 40,8 & $36,5-45,1$ & 14 & 16,1 & $13-19,2$ \\
\hline 96. & 9 & 46,4 & $41,1-51,8$ & 6 & 20,3 & $15,8-24,8$ \\
\hline 120. & 5 & 52,6 & $45,6-59,6$ & 2 & 22,5 & $17,2-27,8$ \\
\hline
\end{tabular}

$\mathrm{Cl}$ (confidence interval) - przedział ufności 
samym ocenić, jaki czas leczenia przeciwkrzepliwego u danego chorego będzie optymalny. W wymienionych skalach, a także w skali HERD002, jednym z czynników ocenianych w prognozowaniu nawrotu VTE jest stężenie D-dimeru we krwi [15]. W metaanalizie 7 prospektywnych badań obejmujących 1818 chorych z proksymalną zakrzepicą żylną lub z PE oceniono związek między stężeniem D-dimeru a ryzykiem nawrotu VTE. U około połowy pacjentów powodem leczenia był epizod idiopatycznej VTE. Pacjenci przyjmowali leki przecikrzepliwe - początkowo heparynę, następnie przez co najmniej 3 miesiące antagoniste witaminy $\mathrm{K}$ (VKA, vitamin K antagonist). W metaanalizie oceniano, czy na wartość prognostyczną oznaczeń D-dimeru wpływają wiek pacjentów ( $\leq 65$. rż. lub > 65. rż.) i czas oznaczania stężenia D-dimeru po zakończeniu leczenia przeciwkrzepliwego (< 3 tygodni, 3-5 tygodni, > 5 tygodni). Wśród 1818 pacjentów objętych analizą u 992 (54,6\%) stwierdzono prawidłowe stężenie D-dimeru, a u pozostałych 826 (45,4\%) było ono podwyższone. Wykazano, że ryzyko nawrotu VTE u chorych z prawidłowym stężeniem D-dimeru wyniosło 3,7/100 pacjentolat (95-proc. przedział ufności [Cl, confidence interval] 3,2-4,3), a wśród pacjentów z podwyższonym stężeniem D-dimeru - 8,8/100 pacjentolat $(95 \%$ Cl 6,2-11,3).Wskaźnik ryzyka w przypadku podwyższonych stężeń D-dimeru w przewidywaniu nawrotu VTE wyniósł 2,59 (95\% Cl 1,9-3,52). U 220 pacjentów $(13,6 \%)$ stężenie D-dimeru oznaczono przed upływem 3 tygodni od zakończenia leczenia przeciwkrzepliwego, u 1028 (63,7\%) w okresie 3-5 tygodni, a u 365 badanych $(22,7 \%)-$ w czasie dłuższym niż 5 tygodni. We wszystkich tych grupach wykazano, że stężenie D-dimeru ma znaczenie prognostyczne. Przedstawione wyniki przemawiają za tym, by przy podejmowaniu decyzji o wydłużeniu czasu leczenia przeciwkrzepliwego u chorych po epizodzie idiopatycznej VTE oznaczać stężenie D-dimeru niezależnie od wieku pacjenta oraz czasu wykonania oznaczeń [16].

\section{Długotrwałe leczenie przeciwkrzepliwe u chorych z VTE}

Celem leczenia ostrej DVT jest zapobieganie zgonom i inwalidztwu, nadciśnieniu płucnemu i chorobie żył obwodowych. Dalszym celem jest zapobieganie nawrotom choroby oraz rozwojowi przewlekłej choroby żylnej.

Leczenie VTE przebiega w dwóch etapach:

- długotrwałego leczenia przeciwkrzepliwego trwającego 3 miesiące;

- przedłużonej profilaktyki przeciwzakrzepowej - jej okresu nie ustalono jednoznacznie [8].

Okres leczenia przeciwkrzepliwego zależy od postaci i lokalizacji VTE, a także od ryzyka krwawienia. U wszystkich pacjentów z DVT odcinka proksymalnego i u pacjentów z PE rekomenduje się leczenie przeciwkrzepliwe trwające nie krócej niż 3 miesiące [8].
W pierwszych 3 miesiącach (okres długotrwałego leczenia przeciwkrzepliwego) zaleca się stosowanie:

- doustnych bezpośrednich inhibitorów czynnika Xa (apiksabanu, edoksabanu lub riwaroksabanu) lub

- bezpośrednich doustnych inhibitorów czynnika Ila (dabigatranu), lub

- VKA [8].

Leczenie za pomocą VKA w ciągu pierwszych 3 miesięcy jest podobnie efektywne jak stosowanie doustnych inhibitorów czynnika Xa i lla, ale w badaniach klinicznych zaobserwowano i potwierdzono zwiększoną częstość powikłań krwotocznych w trakcie stosowania VKA, dlatego jest to terapia drugiego wyboru [8].

Szczególną grupę chorych stanowią ci, u których VTE wystąpiła w przebiegu choroby nowotworowej. U tych chorych zaleca się długotrwałe stosowanie heparyn drobnocząsteczkowych [8].

\section{Przedłużona profilaktyka przeciwzakrzepowa u chorych z VTE - u jakich chorych, jaki lek i jak długo należy ją stosować?}

Po zakończeniu 3-miesięcznego okresu długotrwałego leczenia przeciwkrzepliwego należy oszacować ryzyko nawrotu VTE i ryzyko krwawienia powstałe wskutek stosowania tego leczenia i podjąć decyzję odnośnie do kontynuowania lub zaprzestania go. Prawdopodobieństwo nawrotu VTE ocenia się, analizując:

- płeć (mężczyźni są obarczeni wyższym ryzykiem nawrotu niż kobiety);

- wiek (ryzyko u młodszych pacjentów jest wyższe);

- obecność rezydualnych skrzeplin;

- stężenie D-dimeru [8].

Podstawą decyzji dotyczącej przerwania terapii przeciwkrzepliwej powinna być analiza prawdopodobieństwa wystąpienia poważnych powikłań krwotocznych. Czynniki ryzyka poważnych krwawień według zaleceń American College of Chest Physicians (ACCP) z 2016 roku są następujące:

- wiek ponad 65 lat;

- powikłanie krwotoczne w wywiadzie;

- nowotwór złośliwy, obecność przerzutów nowotworu złośliwego;

- niewydolność narządowa: nerek, wątroby;

- trombocytopenia;

- udar mózgu w wywiadzie;

- cukrzyca;

- niedokrwistość;

- terapia przeciwpłytkowa;

- niedostateczna kontrola leczenia przeciwkrzepliwego;

- współistniejące poważne choroby z zaburzeniami funkcjonowania;

- niedawno wykonany zabieg chirurgiczny;

- częste urazy w wywiadzie; 
Tabela 3. Wskazówki American College of Chest Physicians (ACCP) dotyczące stosowania leczenia przeciwkrzepliwego po 3 miesiącach jego przedłużonego stosowania u chorych z żylną chorobą zakrzepowo-zatorową (źródło [9])

\begin{tabular}{|c|c|c|c|}
\hline \multirow[t]{2}{*}{ Grupa ryzyka nawrotu zakrzepicy } & \multicolumn{3}{|c|}{ Grupa ryzyka krwawienia } \\
\hline & Niskie & Umiarkowane & Wysokie \\
\hline Proksymalna DVT lub PE sprowokowana zabiegiem chirurgicznym & Przerwać* & Przerwać* & Przerwać* \\
\hline $\begin{array}{l}\text { Proksymalna DVT lub PE sprowokowana przez niechirurgiczny przejściowy } \\
\text { czynnik ryzyka }\end{array}$ & Przerwać & Przerwać & Przerwać* \\
\hline $\begin{array}{l}\text { Izolowana dystalna DVT sprowokowana przez zabieg chirurgiczny lub } \\
\text { przejściowy czynnik ryzyka }\end{array}$ & Przerwać* & Przerwać* & Przerwać* \\
\hline Pierwszy niesprowokowany epizod proksymalnej DVT lub PE & Kontynuować & Kontynuować & Przerwać* \\
\hline Drugi niesprowokowany epizod proksymalnej DVT lub PE & Kontynuować* & Kontynuować & Przerwać \\
\hline DVT lub PE i aktywna choroba nowotworowa & Kontynuować* & Kontynuować* & Kontynuować \\
\hline
\end{tabular}

- choroba alkoholowa;

- stosowanie niesteroidowych leków przeciwzapalnych;

- znacznie ograniczona zdolność poruszania się. Wyróżniono następujące kategorie wystąpienia powikłań krwotocznych:

- małe - nie stwierdza się czynników wymienionych powyżej, a roczne ryzyko poważnych krwawień wynosi $0,8 \%$;

- umiarkowane - stwierdza się jeden z wymienionych powyżej czynników, a roczne ryzyko poważnych krwawień wynosi 1,6\%;

- duże - stwierdza się co najmniej 2 czynniki ryzyka krwawienia, a roczne ryzyko poważnych krwawień wynosi 6,5\% [8].

W tabeli 3 przedstawiono zalecenia ACCP [9] dotyczące stosowania leczenia przeciwkrzepliwego po 3 miesiącach leczenia w wybranych grupach chorych zależnie od manifestacji i lokalizacji VTE oraz ryzyka krwawienia.

U chorych, w których stosuje się przedłużoną profilaktyke przeciwzakrzepową (okres po pierwszych 3 miesiącach terapii), można kontynuować podawanie wybranego wcześniej leku. Zmiana leczenia jest wskazana w przypadku wstąpienia działań niepożądanych lub jeśli konieczne jest zwiększenie bezpieczeństwa terapii. W przedłużonej profilaktyce przeciwzakrzepowej stosuje się jeden z wymienionych niżej leków:

- doustny bezpośredni inhibitor czynnika Xa (apiksaban, riwaroksaban);

- inhibitor czynnika lla (dabigatran);

- VKA;

- sulodeksyd [17].

U pacjentów, u których ryzyko wystąpienia powikłań krwotocznych oceniono jako małe lub umiarkowane, wskazana jest przedłużona profilaktyka przeciwzakrzepowa z zastosowaniem inhibitorów czynnika Xa (apiksaban, edoksaban, riwaroksaban), inhibitorów czynnika Ila (dabigatran), VKA [1] lub sulodeksydu (tylko przypadki
DVT) [8]. U chorych z pierwszym epizodem proksymalnej, idiopatycznej DVT, u których ryzyko powikłań krwotocznych jest duże, eksperci opracowujący zalecenia ACCP 2016 nie rekomendują przedłużania leczenia przeciwkrzepliwego [9]. Stanowisko ekspertów opracowujących „Konsensus polski” z 2017 roku na podstawie wyników badania SURVET (Secondary Prevention of Recurrent Deep Vein Thrombosis) jest odmienne i polscy eksperci w tej grupie chorych rekomendują stosowanie sulodeksydu ze względu na wysoki profil bezpieczeństwa tego leku i akceptowalna efektywność [8, 17]. U chorych z pierwszym epizodem idiopatycznej PE, u których ryzyko powikłań krwotocznych jest duże, eksperci opracowujący zalecenia ACCP nie rekomendują stosowania przedłużonej profilaktyki przeciwzakrzepowej [9]. Polscy eksperci, opracowujący „Konsensus polski” z 2017 roku, rekomendują jednak przedłużoną profilaktykę przeciwzakrzepową doustnymi inhibitorami czynnika Xa lub Ila w zmniejszonych dawkach [8]. Dane naukowe dotyczące zastosowania sulodeksydu u chorych z PE nie są na tyle wystarczające, by go rekomendować w tym wskazaniu. W wyborze leku przeciwkrzepliwego do prewencji nawrotu VTE należy się także kierować oceną prawdopodobieństwa krwawienia. W tabeli 4 przedstawiono ryzyko nawrotu VTE i ryzyko krwawienia u chorych leczonych sulodeksydem, kwasem acetylosalicylowym (ASA, acetylsalicylic acid) oraz doustnymi antykoagulantami [17-22].

$\mathrm{U}$ chorych leczonych sulodeksydem obserwowano korzystny profil bezpieczeństwa i skuteczności leczenia, co wykazano w badaniu SURVET. Włączono do niego 615 pacjentów z pierwszym epizodem niesprowokowanej zakrzepicy żylnej, którzy byli leczeni przeciwkrzepliwie 3-12 miesięcy. Chorych poddano randomizacji do grupy otrzymującej sulodeksyd 2 razy/dobę w dawce 500 LSU (lipasemic units) lub do grupy przyjmującej placebo. Pierwszorzędowy punkt końcowy - nawrót VTE - stwierdzono u 15 (z 307) chorych otrzymujących sulodeksyd oraz u 30 chorych (z 308) otrzymujących placebo (współczyn- 
Tabela 4. Ryzyko nawrotu żylnej choroby zakrzepowo-zatorowej (VTE, venous thromboembolism) oraz ryzyko krwawienia u chorych leczonych sulodeksydem, kwasem acetylosalicylowym oraz doustnymi antykoagulantami (opracowano na podstawie [17-22])

\begin{tabular}{|c|c|c|c|c|c|c|}
\hline Badanie & Leczenie & $\begin{array}{l}\text { Czas leczenia } \\
\text { (mies.) }\end{array}$ & \multicolumn{2}{|c|}{ Ryzyko nawrotu VTE v. placebo } & \multicolumn{2}{|c|}{$\begin{array}{l}\text { Ryzyko klinicznie istotnego } \\
\text { krwawienia v. placebo }\end{array}$} \\
\hline SURVET [17] & Sulodeksyd & 24 & $\begin{array}{c}0,4 \\
(0,27-0,92)\end{array}$ & $p=0,02$ & $\begin{array}{c}0,97 \\
(0,14-6,88)\end{array}$ & $p=0,98$ \\
\hline $\begin{array}{l}\text { ASPIRE [18] + } \\
\text { WARFASA [19] }\end{array}$ & $\begin{array}{c}\text { Kwas acetylo- } \\
\text { salicylowy }\end{array}$ & $24(48)$ & $\begin{array}{c}0,68 \\
(0,51-0,90)\end{array}$ & $p=0,008$ & $\begin{array}{c}1,50 \\
(0,72-3,14)\end{array}$ & $p=0,28$ \\
\hline RE-SONATE [20] & Dabigatran & 6 & $\begin{array}{c}0,08 \\
(0,02-0,25)\end{array}$ & $p<0,01$ & $\begin{array}{c}2,92 \\
(1,52-5,60)\end{array}$ & $p=0,001$ \\
\hline EINSTEIN [21] & Riwaroksaban & 12 & $\begin{array}{c}0,18 \\
(0,09-0,39)\end{array}$ & $p<0,001$ & $\begin{array}{c}5,19 \\
(2,13-11,7)\end{array}$ & $p<0,001$ \\
\hline AMPLIFY [22] & $\begin{array}{l}\text { Apiksaban } \\
(2,5 \mathrm{mg})\end{array}$ & 12 & $\begin{array}{c}0,19 \\
(0,11-0,33)\end{array}$ & - & $\begin{array}{c}1,20 \\
(0,69-2,10)\end{array}$ & NA \\
\hline AMPLIFY [22] & $\begin{array}{l}\text { Apiksaban } \\
\text { (5 mg) }\end{array}$ & 12 & $\begin{array}{c}0,20 \\
(0,11-0,34)\end{array}$ & - & $\begin{array}{c}1,62 \\
(0,96-2,73)\end{array}$ & NA \\
\hline
\end{tabular}

nik ryzyka [HR, hazard ratio] 0,49, 95\% Cl 0,27-0,92; $p=0,02)$. Nie obserwowano natomiast różnic w zakresie częstości występowania krwawień. W obu grupach u 2 pacjentów odnotowano klinicznie istotne krwawienia, nie obserwowano żadnych krwawień definiowanych jako duże [17]. Brak istotnych krwawień jest czynnikiem wyróżniającym sulodeksyd spośród leków stosowanych u chorych w profilaktyce nawrotu VTE.

\section{Opis i omówienie przypadku klinicznego}

Pacjent w wieku 72 lat, leczony w poradni kardiologicznej, zgłosił się na wizytę z powodu nieuregulowanych wartości ciśnienia tętniczego oraz narastających dolegliwości bólowych kończyn dolnych. W wywiadzie stwierdzono:

- stabilna choroba wieńcowa, po przezskórnej interwencji wieńcowej (PCl, percutaneous coronary intervention) gałęzi przedniej zstępującej lewej tętnicy wieńcowej (LAD, left anterior descending) z implantacją stentu powlekanego 2 lata temu;

- chromanie przestankowe stopnia IIA w skali Fontaine'a;

- przejściowy epizod niedokrwienny mózgu (TIA, transient ischemic attack) 2 lata temu;

- nadciśnienie tętnicze 3. stopnia według European Society of Cardiology;

- niewydolność serca z zachowaną funkcją skurczową lewej komory;

- hipercholesterolemia;

- cukrzyca typu 2;

- palenie tytoniu (30 paczkolat);

- otyłość (wskaźnik masy ciała [BMI, body mass index] $\left.33 \mathrm{~kg} / \mathrm{m}^{2}\right)$;
- VTE: epizod DVT kończyn dolnych (udowej) niesprowokowany rok temu;

- zespół pozakrzepowy.

Chory w trakcie wizyty zgłaszał bóle głowy z towarzyszącymi wysokimi wartościami ciśnienia tętniczego (w pomiarach gabinetowych 160/100 mm Hg, w pomiarach domowych maks. 155/90 mm Hg) oraz narastające od kilku miesięcy bóle kończyn dolnych, głównie łydek, rozpoczynające się po przejściu 200-300 metrów. Nie zgłaszał typowych bólów wieńcowych. W badaniu elektrokardiograficznym (EKG) uwidoczniono rytm zatokowy o prawidłowej częstości 75/min oraz cechy przerostu lewej komory. Obserwowano wzmożone zaczerwienie z towarzyszącą wysypką drobnoplamistą i stwardnienie skóry oraz obrzęk łydki w kończynie, w której wystąpiła uprzednio zakrzepica żyły udowej. W badaniach laboratoryjnych spośród nieprawidłowości stwierdzono stężenie cholesterolu frakcji LDL (low-density lipoprotein) wynoszące $125 \mathrm{mg} /$ /dl. Chory dotychczas stosował ASA w dawce $75 \mathrm{mg} 1 \mathrm{raz}$, nebiwolol w dawce $5 \mathrm{mg} 1 \mathrm{raz}$, ramipril w dawce $10 \mathrm{mg}$ $1 \mathrm{raz}$, atorwastatynę $\mathrm{w}$ dawce $20 \mathrm{mg} 1 \mathrm{raz}$, metforminę w dawce $750 \mathrm{mg} 3$ razy, okresowo suplementował potas i magnez. Leczenie warfaryną z powodu zakrzepicy żyły udowej chory zakończył pół roku temu po półrocznym okresie stosowania leku; w trakcie leczenia za pomoca VKA obserwował uporczywe krwawienia z nosa i okresowo niedostateczną kontrolę międzynarodowego współczynnika znormalizowanego (INR). U prezentowanego pacjenta zmodyfikowano leczenie następująco: ASA w dawce 75 mg 1 raz, sulodeksyd 2 razy/dobę w dawce 500 LSU (2 kapsułki $2 \times /$ d.), perindopril $z$ indapamidem w preparacie złożonym w dawce 10/2,5 mg z suplementacją 
potasu, nebwiolol w dawce $5 \mathrm{mg} 1 \mathrm{raz}$, rosuwastatyne w dawce $20 \mathrm{mg} 1 \mathrm{raz}$, metformine $\mathrm{w}$ dawce $750 \mathrm{mg}$ 3 razy. W charakterystyce produktu leczniczego sulodeksydu brakuje adnotacji odnośnie do przeciwwskazań stosowania tego leku łącznie z ASA. W badaniu SURVEY u $25 \%$ chorych stosowano sulodeksyd z ASA. Skojarzenie to jest bezpieczne. Chory zjawił się na wizycie kontrolnej po 3 miesiącach. Zgłaszał istotną poprawę samopoczucia i lepszą kontrolę ciśnienia tętniczego, w pomiarach domowych wykonywanych rano i wieczorem wartości ciśnienia nie przekraczały $135 / 85 \mathrm{~mm} \mathrm{Hg}$. W badaniach laboratoryjnych stwierdzono stężenie cholesterolu frakcji LDL równe 68 mg/dl, co odpowiadało zalecanej wartości docelowej poniżej $70 \mathrm{mg} / \mathrm{dl}$. Chory zgłaszał także istotną poprawę tolerancji wysiłku. Bóle kończyn dolnych pojawiały się sporadycznie, zwykle podczas przejścia długich dystansów, powyżej 1000 metrów chory nie obserwował żadnych dolegliwości. Zmniejszyły się także obrzęk kończyny dolnej i rumień skórny, choć stwardnienie skóry i tkanki podskórnej pozostało. Niestety, chory nadal palił papierosy, choć ich liczbę ograniczył do 10-15 papierosów dziennie. Utrzymano zalecenia dotyczące leczenia takie jak na poprzedniej wizycie. Chory, mimo zaleceń, nie stosował kompresoterapii w prewencji nawrotu VTE.

$\mathrm{U}$ opisywanego chorego na uwage zasługuje przede wszystkim fakt bardzo wysokiego ryzyka sercowo-naczyniowego. Chory po rewaskularyzacji tętnicy wieńcowej, TIA oraz ze współistniejącą cukrzycą to pacjent z grupy najwyższego ryzyka wystąpienia epizodu sercowo-naczyniowego, u którego konieczne jest restrykcyjne dążenie do osiągnięcia docelowych wartości ciśnienia tętniczego oraz stężenia cholesterolu frakcji LDL. Zmiana leczenia hipotensynego i hipolipemizującego pozwoliła na osiągnięcie wartości docelowych ciśnienia tętniczego i wspomnianej frakcji cholesterolu. Kolejnym elementem leczenia istotnym dla rokowania omawianego chorego jest profilaktyka nawrotu VTE. Pacjent przebył zakrzepicę żyły udowej, która nie była indukowana żadnym identyfikowalnym czynnikiem. Ryzyko nawrotu VTE u chorego z zakrzepicą proksymalną, niesprowokowaną, palącego papierosy jest wysokie i z upływem czasu istotnie się zwiększa. U prezentowanego chorego leczenie VKA stosowano przez 6 miesięcy po epizodzie zakrzepicy. Zgodnie z wytycznymi amerykańskimi i polskimi $[8,9]$ okres długotrwałego leczenia przeciwkrzepliwego po DVT wynosi 3 miesiące. Po tym czasie należy podjąć decyzję odnośnie do utrzymania długotrwałego leczenia przeciwkrzepliwego lub zaprzestania stosowania profilaktyki przeciwzakrzepowej. Czas trwania leczenia u opisywanego chorego ukazuje trudności w podejmowaniu decyzji dotyczących okresu leczenia przeciwkrzepliwego u chorych z VTE, co wynika z obawy przed nawrotem choroby i powikłaniami krwotocznymi jednocześnie. Celem zastosowania sulodeksydu u omawianego chorego było przede wszystkim obniżenie ryzyka wystąpienia nawrotu VTE. Sulodeksyd jest oczyszczoną mieszaniną glikozaminoglikanów uzyskiwaną ze śluzówki jelit bydlęcych, składającą się z heparyny szybko przemieszczającej się w polu elektroforezy (80\%) i siarczanu dermatanu (20\%). Działania przeciwzakrzepowe, profibrynolityczne, przeciwzapalne, hamujące procesy włóknienia oraz protekcyjne w odniesieniu do komórek śródbłonka naczyniowego czynią z sulodeksydu lek o szerokim spektrum działania, a przede wszystkim o działaniu przeciwzakrzepowym. Działanie to udowodniono w odniesieniu do sulodeksydu w badaniu SURVET [17] - stosowany doustnie w dawce 500 LSU 2 razy/dobę łącznie z kompresjoterapią przez 2 lata (po zakończeniu standardowego leczenia przeciwkrzepliwego) obniżał o 55\%, w porównaniu z placebo, ryzyko nawrotu VTE, nie zwiększając ryzyka powikłań krwotocznych. Sulodeksyd może być stosowany w przedłużonym leczeniu przeciwkrzepliwym u chorych obciążonych zwiększonym ryzykiem powikłań krwotocznych i umiarkowanym ryzykiem nawrotu VTE, a także jako dodatkowe zabezpieczenie u chorych cechujących się niskim ryzykiem nawrotu VTE, u osób w podeszłym wieku, a także w przypadku nietolerancji ASA [8]. Prezentowany chory od wielu lat był leczony z powodu cukrzycy. Broekhuizen i wsp. [23] stwierdzili scieńczenie warstwy glikokaliksu w śródbłonku naczyń krwionośnych chorych na cukrzycę, co powodowało większą przepuszczalność ich ściany dla makrocząsteczek. Stosowanie przez 2 miesiące sulodeksydu w dawce 200 mg/dobę spowodowało pogrubienie warstwy glikokaliksu na powierzchni śródbłonka z jednoczesnym ograniczeniem przepuszczalności ściany naczynia dla albumin [23]. Kolejnym korzystnym efektem działania sulodeksydu u tego chorego było wydłużenie dystansu chromania przestankowego. Coccheri i wsp. [24] wykazali, że u chorych z chromaniem przestankowym 6-miesięczna terapia sulodeksydem spowodowała istotne wydłużenie maksymalnego dystansu chodzenia bez odczuwania bólu (wydłużenie o 142,3 \pm $\pm 15,8 \mathrm{~m} ; \mathrm{p}<0,001$ ) i efekt ten nie zależał od obecności cukrzycy lub braku tej choroby.

W metaanalizie 8 badań obejmujących 849 pacjentów z miażdżycą zarostową tętnic obwodowych potwierdzono wcześniejsze obserwacje [25]. Stosowanie sulodeksydu spowodowało wydłużenie dystansu chodu bez dolegliwości bólowych o 36\% [25]. U chorych otrzymujących ten lek obserwowano także istotne zmiany parametrów biochemicznych, w tym zmniejszenie stężenia triglicerydów o 28\% oraz fibrynogenu o 13\% i wzrost stężenia cholesterolu frakcji HDL (high-density lipoprotein) o 24\% [25]. Odczyn zapalny jest istotnym czynnikiem w rozwoju przewlekłych chorób obwodowych naczyń tętniczych. Sulodeksyd wykazuje działanie przeciwzapalne, między innymi dzięki udowodnionemu obniżaniu stężeń białka ostrej fazy (białka C-reaktywnego [CRP, C-reactive protein]) i fibrynogenu [26].

$\mathrm{U}$ przedstawionego chorego zastosowano optymalne leczenie przeciwpłytkowe i przeciwkrzepliwe - chory był 
po TIA i rewaskularyzacji wieńcowej, z miażdżycą tętnic kończyn dolnych i po przebytym epizodzie VTE - leczenie hipolipemizujące i hipotensyjne. Niestety, nie udało się przekonać pacjenta do zaprzestania palenia tytoniu ani uzyskać u niego zmniejszenia masy ciała, co w profilaktyce nawrotów VTE jest tak samo istotne jak w profilaktyce miażdżycy.

\section{Podsumowanie}

Żyına choroba zakrzepowo-zatorowa - zarówno pod postacią PE, jak i DVT - charakteryzuje się znaczną nawrotowością, istotnie się zwiększającą z czasem upływającym od zachorowania. Optymalne leczenie w prewencji nawrotu choroby powinno być skuteczne i bezpieczne pod względem możliwych powikłań krwotocznych. Sulodeksyd jest reko- mendowany w dokumencie „Konsensus polski” z 2017 roku w prewencji nawrotów DVT. W przypadku przedłużonej profilaktyki przeciwzakrzepowej u pacjentów z idiopatyczną DVT i obciążonych dużym ryzykiem powikłań krwotocznych autorzy dokumentu zalecają, aby nie przerywać antykoagulacji i stosować sulodeksyd. Sulodeksyd dzięki unikatowemu połączeniu działania hamującego wewnątrznaczyniowy odczyn zapalny, działania protekcyjnego w stosunku do śródbłonka, działania przeciwzakrzepowego i poprawiającego mikrokrążenie znajduje zastosowanie zarówno u pacjentów z chorobami naczyń żyınych, jak i tętniczych.

\section{Konflikt interesów}

BWK - honoraria za wykłady dla firm: Egis, Krka, MSD, Mylan, Servier.

\section{Abstract}

Venous thromboembolism (VTE) is a frequent cause of death, both its first manifestation and subsequent recurrences. The risk of the recurrence is highest in patients with unprovoked VTE and in those with deep vein thrombosis in the proximal segment. After an obligatory 3-month anticoagulant therapy, indications for long-term anticoagulant therapy should be considered in patients with VTE. The paper presents the current state of knowledge on the prophylaxis of recurrences and a case report describing the daily choices made in patients at highest cardiovascular risk.

Key words: sulodexide, deep vein thrombosis

Folia Cardiologica 2017; 12, 6: 580-588

\section{Piśmiennictwo}

1. Perrier A, Bounameaux H, Morabia A, et al. Diagnosis of pulmonary embolism by a decision analysis-based strategy including clinical probability, D-dimer levels, and ultrasonography: a management study. Arch Intern Med. 1996; 156(5): 531-536, doi: 10.1001/ /archinte.1996.00440050079009, indexed in Pubmed: 8604959.

2. Partsch $\mathrm{H}$, Kechavarz B, Mostbeck A, et al. Frequency of pulmonary embolism in patients who have iliofemoral deep vein thrombosis and are treated with once- or twice-daily low-molecular-weight heparin. J Vasc Surg. 1996; 24(5): 774-782, doi: 10.1016/s0741-5214(96)70012-5, indexed in Pubmed: 8918323.

3. Pesavento R, Lusiani L, Visonà A, et al. [Prevalence of clinically silent pulmonary embolism in deep venous thrombosis of the legs]. Minerva Cardioangiol. 1997; 45(7-8): 369-375, indexed in Pubmed: 9463172.

4. Girard P, Musset D, Parent F, et al. High prevalence of detectable deep venous thrombosis in patients with acute pulmonary embolism. Chest. 1999; 116(4): 903-908, doi: 10.1378/chest.116.4.903, indexed in Pubmed: 10531151.

5. Bénard E, Lafuma A, Ravaud P. [Epidemiology of venous thromboembolic disease]. Presse Med. 2005; 34(6): 415-419, indexed in Pubmed: 15902870.
6. Stein DP, Hull RD, Kayali F, et al. Venous thromboembolism according to age. Arch Intern Med. 2004; 164(20): 2260-2265, doi: 10.1001/ /archinte.164.20.2260, indexed in Pubmed: 15534164.

7. Zawilska K. Komentarz do zaktualizowanych polskich wytycznych profilaktyki i leczenia żylnej choroby zakrzepowo-zatorowej. Med Prakt. 2005; 6: 157-167.

8. Tomkowski W, Kuca P, Urbanek T, et al. Żylna choroba zakrzepowo-zatorowa-wytyczne profilaktyki, diagnostyki i terapii. Konsensus polski 2017. Acta Angiol. 2017; 23: 73-113.

9. Kearon C, Akl EA, Ornelas J, et al. Antithrombotic Therapy for VTE Disease: CHEST Guideline and Expert Panel Report. Chest. 2016; 149(2): 315-352, doi: 10.1016/j.chest.2015.11.026, indexed in Pubmed: 26867832.

10. Prandoni P, Noventa F, Ghirarduzzi A, et al. The risk of recurrent venous thromboembolism after discontinuing anticoagulation in patients with acute proximal deep vein thrombosis or pulmonary embolism. A prospective cohort study in 1,626 patients. Haematologica. 2007; 92(2): 199-205, doi: 10.3324/haematol.10516, indexed in Pubmed: 17296569.

11. Baglin T, Douketis J, Tosetto A, et al. Does the clinical presentation and extent of venous thrombosis predict likelihood and type of 
recurrence? A patient-level meta-analysis. J Thromb Haemost. 2010; 8(11): 2436-2442, doi: 10.1111/j.1538-7836.2010.04022.x, indexed in Pubmed: 20723032.

12. Palareti G, Cosmi B, Legnani C, et al. PROLONG Investigators. D-dimer testing to determine the duration of anticoagulation therapy. $N$ Engl J Med. 2006; 355(17): 1780-1789, doi: 10.1056/NEJMoa054444, indexed in Pubmed: 17065639.

13. Tosetto A, lorio A, Marcucci M, et al. Predicting disease recurrence in patients with previous unprovoked venous thromboembolism: a proposed prediction score (DASH). J Thromb Haemost. 2012; 10(6): 1019-1025, doi: 10.1111/j.1538-7836.2012.04735.x, indexed in Pubmed: 22489957.

14. Eichinger S, Heinze G, Kyrle PA, et al. Risk assessment of recurrence in patients with unprovoked deep vein thrombosis or pulmonary embolism: the Vienna prediction model. Circulation. 2010; 121(14): 1630-1636, doi: 10.1161/CIRCULATIONAHA.109.925214, indexed in Pubmed: 20351233.

15. Ensor J, Riley RD, Moore D, et al. Systematic review of prognostic models for recurrent venous thromboembolism (VTE) post-treatment of first unprovoked VTE. BMJ Open. 2016; 6(5): e011190, doi: 10.1136/ /bmjopen-2016-011190, indexed in Pubmed: 27154483.

16. Douketis J, Tosetto A, Marcucci M, et al. Patient-level meta-analysis: effect of measurement timing, threshold, and patient age on ability of D-dimer testing to assess recurrence risk after unprovoked venous thromboembolism. Ann Intern Med. 2010; 153(8): 523-531, doi: 10.7326/0003-4819-153-8-201010190-00009, indexed in Pubmed: 20956709.

17. Kearon C, AkI EA, Ornelas J, et al. Antithrombotic Therapy for VTE Disease: CHEST Guideline and Expert Panel Report. Chest. 2016; 149(2): 315-352, doi: 10.1016/j.chest.2015.11.026, indexed in Pubmed: 26867832.

18. Andreozzi GM, Bignamini AA, Davì G, et al. SURVET Study Investigators. Sulodexide for the Prevention of Recurrent Venous Thromboembolism: The Sulodexide in Secondary Prevention of Recurrent Deep Vein Thrombosis (SURVET) Study: A Multicenter, Randomized, Double-Blind, Placebo-Controlled Trial. Circulation. 2015; 132(20): 1891-1897, doi: 10.1161/CIRCULATIONAHA.115.016930, indexed in Pubmed: 26408273.
19. Brighton TA, Eikelboom JW, Mann K, et al. ASPIRE Investigators. Low-dose aspirin for preventing recurrent venous thromboembolism. N Engl J Med. 2012; 367(21): 1979-1987, doi: 10.1056/NEJMoa1210384, indexed in Pubmed: 23121403.

20. Becattini C, Agnelli G, Schenone A, et al. WARFASA Investigators. Aspirin for preventing the recurrence of venous thromboembolism. N Engl J Med. 2012; 366(21): 1959-1967, doi: 10.1056/NEJMoa1114238, indexed in Pubmed: 22621626.

21. Schulman S, Kearon C, Kakkar AK, et al. RE-MEDY Trial Investigators, RE-SONATE Trial Investigators. Extended use of dabigatran, warfarin, or placebo in venous thromboembolism. N Engl J Med. 2013; 368(8): 709 -718, doi: 10.1056/NEJMoa1113697, indexed in Pubmed: 23425163.

22. Bauersachs R, Berkowitz SD, Brenner B, et al. EINSTEIN Investigators. Oral rivaroxaban for symptomatic venous thromboembolism. N Engl J Med. 2010; 363(26): 2499-2510, doi: 10.1056/NEJMoa1007903, indexed in Pubmed: 21128814.

23. Agnelli G, Buller HR, Cohen A, et al. AMPLIFY Investigators. Oral apixaban for the treatment of acute venous thromboembolism. $\mathrm{N}$ Engl J Med. 2013; 369(9): 799-808, doi: 10.1056/NEJMoa1302507, indexed in Pubmed: 23808982.

24. Broekhuizen LN, Lemkes BA, Mooij HL, et al. Effect of sulodexide on endothelial glycocalyx and vascular permeability in patients with type 2 diabetes mellitus. Diabetologia. 2010; 53(12): 2646-2655, doi: 10.1007/s00125-010-1910-x, indexed in Pubmed: 20865240.

25. Coccheri S, Scondotto G, Agnelli G, et al. Arterial Arm of the Suavis (Sulodexide Arterial Venous Italian Study) group. Sulodexide in the treatment of intermittent claudication. Results of a randomized, double-blind, multicentre, placebo-controlled study. Eur Heart J. 2002; 23(13): 1057-1065, indexed in Pubmed: 12093059.

26. Gaddi A, Galetti C, Illuminati B, et al. Meta-analysis of some results of clinical trials on sulodexide therapy in peripheral occlusive arterial disease. J Int Med Res. 1996; 24(5): 389-406, doi: 10.1177/03000 6059602400501, indexed in Pubmed: 8895043.

27. Piaggesi A, Abbruzzese L, Mattaliano C, et al. Sulodexide as Adjunctive Therapy in Diabetic Foot Patients With Critical Limb Ischemia Treated With Percutaneous Transluminal Angioplasty. Int J Low Extrem Wounds. 2014; 13(2): 103-109, doi: 10.1177/1534734614534442, indexed in Pubmed: 24861092. 